\title{
ANTIOXIDANT AND ANTIMICROBIAL ACTIVITY OF SOME HERBS VOLATILE OILS AND THEIR ETHANOLIC EXTRACTS \\ El-Gammal, Rania E. ${ }^{*}$ and Sabrene A. Omar** \\ * Food Industries Dept., Fac. of Agric., Mansoura Univ., Egypt \\ ${ }^{\star \star}$ Agricultural Microbiology Dept., Fac. of Agric.., Mansoura Univ, Egypt
}

\begin{abstract}
Antioxidative and antimicrobial properties of volatile oils and their ethanolic extracts from four herbs namely, thyme, rosemary, fennel and marjoram were determined. the volatile oils were analyzed by GC-MS, different compounds were identified, namely carvone, thymol, $\alpha$ - pinene, anisole , caryophyllene, eugenol ..... etc, and about 11 different phenolic compounds were identified namely . Catechien, Chlorogenic acid, Caffien, P-OH Benzoic, Ferrulic, Caffeic, Synergic , Salicylic, Pcoumaric, Cinnamic and Vanillic acids Results indicated that all extracts were varied in their content of phenolic compounds,

Volatile oils and ethanolic extracts obtained from different herbs were evaluated for their antibacterial activities against five strains Gram-positive and Gramnegative pathogenic bacteria: Staphylococcus aureus, Bacillus cereus, Salmonella sp., Shigella flaxnary and Enterobacter sakazakii, respectively and two fungus strains namely , Aspergillus niger and Aspergillus oryazae. Thyme volatile oil proved the superiority over the other volatile oil against the tested microorganisms followed with marjoram volatile oil. Whereas fennel volatile oil had positive effect against tested microorganisms exception with Enterobacter sakazaki, also, inhibitory effect found by thyme, marjoram and rosemary extracts against all tested microorganisms. Results of minimum inhibitory concentration ( MIC ) indicated that both of thyme extract and volatile oil have a strong antimicrobial activity .

Obtained data suggested the possibility to use volatile oil and their ethanolic extracts in food processing to control pathogens for food preservation as well .

Keywords: Volatile oils, ethanolic extracts, DPPH, oxidative stability, rancimat test antimicrobial activity .
\end{abstract}

\section{INTRODUCTION}

Oxidative stability is one of the most important indicators for marinating the quality of edible oils and could be increased using natural and synthetic antioxidants, the effect of antioxidants on the behavior of edible oils is widely investigated, but very little known on the effective of antioxidants on the stabilization of oils (Sendzikiene et al.,2005).

Natural antioxidants may be useful in retarding oxidative deterioration of food materials especially those with high lipid content Hence there is a tendency towards the use of natural antioxidants of herbs and to replace these synthetic ones. The application of natural antioxidants to prevent edible oil rancidity had been studied (Xiong, et al. 2001).

Aromatic plants have been used for centuries as spices and condiments to confer aroma and flavor to food and beverages. Additionally, due to their constituents, medicinal and aromatic plants can act as stabilizer agents, playing an important role in the shelf-life of foods and beverages 
(Salgueiro et al. 2010) but only in the last decade scientific research has focused its interest on their (Karaman et al. 2001).

Volatile oils and their extracts acts as natural sources of antimicrobial and antioxidant compounds (Sagdic etal ., 2003). Volatile oils are natural compounds characterized by a strong odor and are formed by aromatic plants as secondary metabolites (Bakkali et al. , 2008). They are usually obtained by hydro-distillation, steam distillation or dry distillation of a plant or of some parts of it. The main advantage of Eos is that they can be used in any food and are generally recognized as safe (GRAS) (USFDA, 2006)

Volatile oils are made up of many different volatile compounds and have shown to posses antimicrobial properties, volatile oil and plant extracts are arousing increasing interest because of their safe status, their wide acceptance by consumers and their exploitation for potential multi -purpose functions uses. So, volatile oil are the one of the most promising groups of natural compounds for the development of safer antifungal and antibacterial agents .

Use of volatile oil as antimicrobial agents in food systems may be considered as an additional intrinsic determinant to increase the safety and shelf life of foods ( Nychas et al. 2003). Food processors, food safety researchers and regulatory agencies have been increasingly concerned with the growing number of food-borne illness outbreaks caused by some pathogens and/or their enterotoxins. Escherichia coli, Staphylococcus aureus, Salmonella spp., Yersinia spp. and Clostridium spp. are responsible for many cases of intestinal disorders, causing vomiting and diarrhoea. Moreover, some microorganisms are also associated with food spoilage, causing economic losses (Demirci, et al. 2008 and Friedman et al. 2002). Global interest in bio preservation of food systems has recently been increased because of great economic costs of deterioration and poisoning of food products by food pathogens. Volatile oils and extracts of various species of edible and medicinal plants, herbs, and spices constitute of very potent natural biologically active agents Use of volatile oils as antimicrobial agents in food systems may be considered as an additional intrinsic determinant to increase the safety shelf life of foods (Nychas et al. 2003 ).

Many spices and herbs exert antimicrobial activity due to their volatile oil fractions. The most common herbs and spices in the miditerarrin region are thyme, fennel, ginger, mint, basil ..etc , these herbs and spices are widely used as a source of volatile oils for flavoring and recently have been used as a valuable source of the potent antioxidants in food industries

According, This study was carried out to compare between some volatile oils extracted from some herbs namely, thyme, rosemary, fennel and marjoram and their ethanolic extracts as natural antioxidants and antibacterial agents . 


\section{MATERIALS AND METHODS}

\section{Materials:}

Palm oil, Tertiary Butyl Hydroquinone (TBHQ) were obtained from Misr Oil and Soap Company, Mansoura, Egypt.

Herbs : Dried herbs namely, Thyme (Thymus. Vulgairs), Fennel (Foeniculum vulgare), Rosemary (Rosmarinus officinalis) and Marjoram (Origanum majorana )were purchased from local market in El-Azhar, Cairo, Egypt.

Microorganisms: Two Gram positive bacteria (Staphylococcus aureus and Bacillus cereus), three Gram negative bacteria (Shigella flaxnary, Salmonella sp. and Enterobacter sakazakii) and two fungal strains (Aspergillus niger and Aspergillus flavus). The bacteria strains were obtained from Dairy Dept., faculty of Agric., Mansoura University and the two fungal strains were obtained from Microbial. Dept., faculty of Agric., Mansoura University.

Chemicals :

DPPH (1.1 Diphenyl 1-2-picrylhydrazl ) was obtained from sigma/ Aldrich company .USA, and Sodium sulphate anhydrous was obtained from ElGomhoria company for El-Gomhoria Co. for trading in Medicines, Chemicals and Medical Supplies, El-Mansoura, Egypt.

Methods:

Separation of volatile oils:

The dried herbs were individually ground by domestic grinder type Moulinex and then pass through 80 mesh sieve, then each herb was extracted using hydro- distilled method for 5 hrs in a Clevenger type apparatus. The oils were dried over anhydrous sodium sulphate and stored in dark bottle for further analysis (Skandamis and Nychas 2001).

Ethanol Extracts: All herbs firstly were dried at $45-50^{\circ} \mathrm{C}$ for an hour using air drying oven (Officine Specializzate, GARBUIO, Essiccatioi, TREVISO, ITALY). Then, it was extracted using a method of maceration with ethanol (500 g dried herb / $500 \mathrm{ml}$ solvent) for 12 hours. After maceration, the extracts were collected, filtered and evaporated with vacuum rotary evaporator (BÜCH, RE 111, SWIZERLAND). The evaporated extracts were collected in dark glass bottles and stored at $3-5^{\circ} \mathrm{C}$ until will be used (Wojdylo et al 2007).

\section{Chemical analysis:}

Identification of volatile oils compounds:

The volatile oils were identified and determined according to Adms, (2001 ) using Gas Chromatography -mass spectroscopy (GC-MASS ) techniques at Food Technology Research Institute, Giza , Egypt .

The operation conditions: Mass selective xl inert detector 5975,obtained results were identified by HP $60908 \mathrm{~N}$.

Extraction and identification of phenolic compounds :

Extractions of phenolic compounds of all herbs were carried out according to the method described by Wojdylo et al., (2007) and were 
determined according to the method described by Waskmundzka et al.,(2007), Which calculated as $\mathrm{mg}$ Gallic acid $/ 100 \mathrm{~g}$ of dry weight material.

- Phenolic compounds of herbs ethanolic extract were identified using high performance liquid chromatography (HPLC ) ,"HP1050" . Food Technology Research Institute, Giza, Egypt .

Radical scavenging assay DPPH:

DPPH radical was determined according to Mau et al., (2004) with minor modifications. The extracts $100,200,250,500,1000 \mu \mathrm{g}$ ) in methanol $(1 \mathrm{~mL})$ was mixed with $4 \mathrm{~mL}$ of $0.004 \%$ methanolic solution of DPPH. The mixture was shaken vigorously and left to stand for $30 \mathrm{~min}$ in dark at $30^{\circ} \mathrm{C}$, and the absorbance was then measured at $517 \mathrm{~nm}$. using Spekol 11, Carl Zeiss Jena, German.

The percent of DPPH discoloration of the samples was calculated according to the equation:-

Antiradical Activity\% =

Absorbance of control - absorbance of sample / absorbance of control .

Oxidative stability of palm oil : :

The influence of different methanolic extracts evaluated on oxidative stability of palm oil was evaluated by the rancimat method using Metrohm 679 as described by De Man and DeMan, (1984 ).Oil without any addition was used as control. The induction period (I.P.) was conducted at $100^{\circ} \mathrm{C}$ and calculated at $25^{\circ} \mathrm{C}$ at Food Technology Research Institute, Giza, Egypt according as described by Pardun and Kroll (1972)) .

Antioxidant Actively (S.F.) = I.P of sample / I.P of control

Increasing Index \%= (I.P of sample - I.P of control / I.P of control) $x 100$.

I.P. $=$ Induction Period

Microbiological experiments:

Conditions for cultivation:

Bacteria were assayed on nutrient agar medium and fungi were assayed on potato dextrose agar media. Bacterial suspensions were adjusted with sterile saline to a concentration of $1.0 \times 10^{6} \mathrm{CFU} / \mathrm{ml}$ and spore suspensions were adjusted with sterile saline to a concentration of $1.0 \times 10^{4} \mathrm{spore} / \mathrm{ml}$. $0.02 \%$ Tween 80 was added to the media to emulsify the oils (Hood et al., 2003).

Assessment of antimicrobial activities :

Agar wells - diffusion method : was used and the antimicrobial test was performed according to the method of Wan et al., (1998)_with some modification. Briefly, $0.5 \mathrm{ml}$ of fresh overnight cultures of the tested bacteria $\left(1.0 \times 10^{6} \mathrm{CFU} / \mathrm{ml}\right)$, and fungi $\left(10^{4} \mathrm{spore} / \mathrm{ml}\right)$ were spread on nutrient agar for bacteria and Potato dextrose agar for fungi in sterilized Petri dishes $(90 \mathrm{~mm}$ diameter). Wells were created using a $6 \mathrm{~mm}$ cork borer. Each well was filled with $10 \mu \mathrm{l}$ of the oils samples. The incubation was carried out at $37^{\circ} \mathrm{C}$ for the bacteria and $30^{\circ} \mathrm{C}$ for the fungi. After $24-48 \mathrm{~h}$ of incubation, the antimicrobial activity was evaluated by measuring the width of the zone of inhibition. Experiments were performed in triplicate.

Minimum Inhibitory Concentrate (MIC):

The Broth dilution method was used to determine the minimum inhibitory concentration (MIC). $0.5 \mathrm{ml}$ of fresh over night tested bacteria and 
fungi were inoculated into tubes containing serial dilutions of volatile oils. All tubes were incubated at $37^{\circ} \mathrm{C}$ and $30^{\circ} \mathrm{C}$ for bacteria and fungi, respectively. Tubes were examined for visible signs of bacterial and fungal growth. The highest dilution without growth is the minimal inhibitory concentration (MIC) (Andrews, 2001).

Statistical analysis: Values represented are the means and standard error , significance was used at $p . \leq 0.05$,(ANOVA) was done using SPSS 17 program for windows.

\section{RESULTS AND DISCUSSIONS}

\section{Separation and identification of volatile compounds in herbs:}

Volatile oils from different herbs were identified and determined_using( GC/MS) analysis. Data presented in Table (1) revealed that the volatile oils from thyme, fennel, rosemary and marjoram which contained a complex mixture consisting of mainly oxygenated mono-and sesquiterpenes mono hydrocarbons different compounds namely, linalool, caryophyllene, terpens and $\alpha$ - pinene

Thyme oil is considered as a source of natural antioxidants . Chemical composition of thyme oil showed a great chemical homogeneity characterized by high amount of thymol (44.5), carvone (11.20) Caryophyllene (14.30\%),. There were some oxygenated monoterpens like Carvacol $(15.5 \%)$ and cadinol $0.51 \%$. Also, some of other volatile compounds were thymoquinone $5.81 \%, \alpha$ - terpene $(0.41 \%)$ and other Alcohols were defined Lanisole $(0.21)$ (Zeyada et al., 2007 ).

Fennel oil is not only use as natural source of food flavoring, but also have a medicinal properties for the treatment of various diseases .The chemical constitutes of commercial fennel oil and its main compounds was tested also, among them cavicol (11.31\%) further more some interesting compounds were identified namely camphor, cryophellene. These compounds followed by some oxygenated mono terpenes Kampheriol (11.21) and phenol (1.32\%) (Adms , 2001)

Marjoram oil is used also as natural flavoring agents nearly 15 compounds were identified, over $50 \%$ of the total volatile compounds from $p$ - cymene $(66.90 \%)$ the major volatile fraction responsible for the aromatic and sharp flavour, kurane and linalool (16.65 and 8.21) respectively terpinol+ terpinene were the predominant oxygenated mono terpenes compound with area $20.22 \%$ other compounds were detected namely limone,. Major volatile detected in this study were in accordance with Yoshizaki et al ., (2010)

Rosemary oil : from abovementioned results in Table (1), it could be noted that rosemary oil are characterized by the presence of large amount from monoterpenes hydrocarbons represented $\alpha$ - Pinene $(22.3 \%)$ and the predominant alcohol was cineole which presented $(28.78 \%$ )and a-terpineol was detected as a minor monoterpenes alcohols. While ester compounds were detected namely, camphor and camphene were( 20.92 and $5.66 \%$ ). these results were in accordance with ( EL -Bastawesy et al. 2008 and Celiktas et al. 2007 ) 
Table (1): Some identified compounds of volatile oils extracted from herbs.

\begin{tabular}{|c|c|c|}
\hline Volatile oils & Identified constituents & Area \% \\
\hline \multirow{14}{*}{$\begin{array}{c}\text { Thyme oil } \\
\text { ( } T_{\text {oil }} \text { ) }\end{array}$} & thymol & 44.5 \\
\hline & carvacol & 15.5 \\
\hline & carvone & 11.20 \\
\hline & thymoquinone & 5.81 \\
\hline & linalool & 0.81 \\
\hline & $\beta$ - caryophyllene & 0.8 \\
\hline & $\alpha$ - pinene & 0.8 \\
\hline & anisole & 0.62 \\
\hline & eugenol & 0.5 \\
\hline & borneol & 0.51 \\
\hline & cadinol & 0.51 \\
\hline & Lanisole & 0.21 \\
\hline & Cayrophyllene & 0.21 \\
\hline & $\alpha$ - terpene & 0.41 \\
\hline \multirow{8}{*}{$\begin{array}{l}\text { Fennel oil } \\
\left(F_{\text {oil }}\right)\end{array}$} & $\alpha$ - pinene & 18.65 \\
\hline & cavicol & 11.31 \\
\hline & Kampheriol & 11.21 \\
\hline & phenol & 1.32 \\
\hline & Bornyol & 0.88 \\
\hline & camphor & 0.74 \\
\hline & Cryophellene & 0.55 \\
\hline & Cineole & 0.32 \\
\hline \multirow{6}{*}{$\begin{array}{l}\text { Marjoram oil } \\
(\text { Ma oil })\end{array}$} & Apiol & 15.62 \\
\hline & a-terpene & 18.32 \\
\hline & p-cymene & 66.90 \\
\hline & linalool & 8.21 \\
\hline & kuarene & 16.65 \\
\hline & Terpineol+ terpinene & 20.22 \\
\hline \multirow{7}{*}{$\begin{array}{l}\text { Rosemary oil } \\
\text { ( Rmoil })\end{array}$} & $\alpha$ - pinene & 22.3 \\
\hline & borneol & 5.6 \\
\hline & b-pinene & 8.79 \\
\hline & Camphene & 5.66 \\
\hline & cineole & 28.78 \\
\hline & Limonene & 2.33 \\
\hline & $\boldsymbol{\alpha}$-terpineol & 5.66 \\
\hline
\end{tabular}

A- Antioxidant Activity of herbs volatile oils and their ethanolic extracts Radical scavenging activity of herbs and spices oils: DPPH is a free radical compound terminating the propagation of radicals and generating and has been widely used to test the free radical unreactive phenoxyl radicals as well as hydroperoxides, the DPPH assay, which measure the ability of compounds to transfer labile $\mathrm{H}$-atoms to radicals, is the commonest method of antioxidants activity evaluation (Brand-Williams et al. 1995 ).

The radical scavenging activity of natural volatile oils from herbs depends greatly on their concentration as resulted in table (2). The highest DPPH was detected in rosemary, thyme and marjoram , were 80.21, $85.02,83.65 \%$, respectively. Thyme oil was found to effective in compare 
with other volatile oils this could be attributed to it is composition of some main components namely carvacol,thymol and carvone. The lowest scavenging activity was $70.54 \%$ detected for fennel oil at the concentrate of $1000 \mu \mathrm{g} / \mathrm{ml}$.

Results in the same table indicated that the ethanolic extracts of herbs were also detected the same trend of scavenging effect were observed, the ethanolic extracts could be arranged designingly as follows: thyme > marjoram $>$ rosemary $>$ marjoram extracts.

These results indicated that natural oils from herbs under investigation have a noticeable effect on scavenging free radicals. These are also attribute to their molecular structure and their content of phenolics and aromatic compounds and $\alpha$ - tocopherol. The antiradical scavenging activity would be related to the substitution of hydroxyl groups in the aromatic rings of phenolics, thus contributing to their hydrogen donating ability. And their content of phenolics compounds and hydroxyl groups contribute markedly to the antioxidant activity. This results were nearly accordance with (Yen et al. 2005).

Table (2): Free radical of scavenging activity on of natural and synthetic antioxidants.

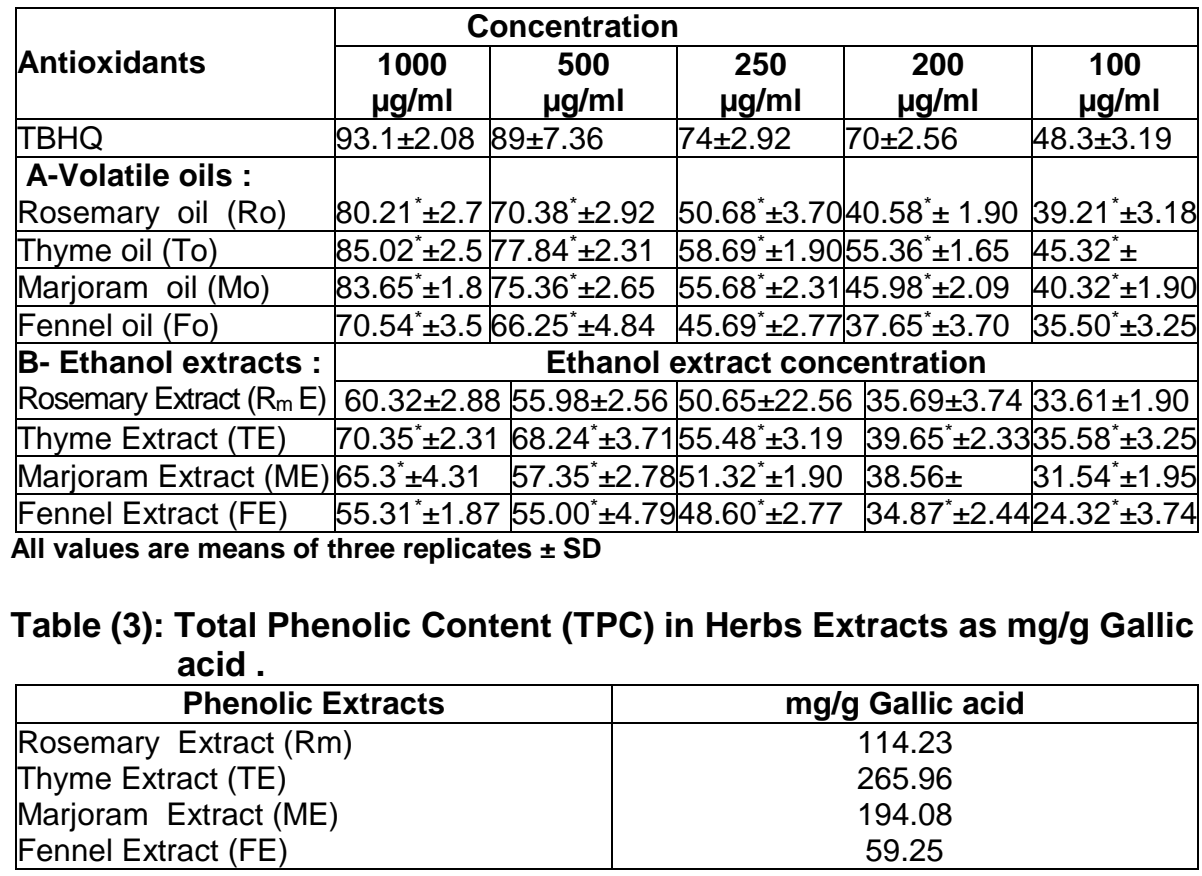

\section{Separation and Identification of phenolic compounds extracts from some herbs :}

Data in Table (3) showed the phenolic compounds content (TPC) in ethanolic extracts which is more frequently used for isolation of antioxidants. 
Ethanolic extracts were always greater in total Polyphenolic compounds as gallic acid.

Data revealed that, the total phenolic compounds of thyme extract represented $265.96 \mathrm{mg} / \mathrm{g}$. followed by marjoram extract exhibited 194.08, rosemary extract was $114.23 \mathrm{mg} / \mathrm{g}$. gallic acid respectively, while Fennel extract exhibited the lowest amount of phenolic content was $59.25 \mathrm{mg} / \mathrm{g}$. gallic acid. These data were in accordance with Moure et al.,(2001) who found that the phenolic compound have high total and active constitutes, these compounds resulted in the superiority, quenching and rerated oxidation of fatty products which herbs and spices where added .

Also, it could be noted that the variations in total phenolic content could be attributed to the specific nature of the plant type, (Kim et al.,1995) stated that the antioxidant activity of extracts produced from herbs and spices was dependent on the type of herbs than the solvent and these results were not doubtful because phenolic compounds in plant foods are largely influenced by genetic factors and environmental conditions. The difference in phenolic content could affect the antioxidant capacity of plants, because many phenolic compounds in plants are good sources of natural antioxidants. Therefore, these phenolic extracts should be used as commercial antioxidants substitution from synthetic ones according to their high amounts of phenolic compounds which protect oil from oxidation and rancidity and at as a synergistic agents (Juliano et al., 2000).

Data in Table (4) showed the identification of different phenolic compounds of investigated herbs. The obtained results indicated that phenolic acids were the most abundant compounds in all examined extracts.

Thyme (Thymus. vulgaris) is usually rich in phenols, these compounds known to have high antioxidants capacity. Results showed that Catechien was the most abundant phenolic compounds represented $94.75 \mathrm{mg} / \mathrm{g}$ followed with Ferrulic acid $49.19 \mathrm{mg} / \mathrm{g}$. these results were in accordance with Zeyada et al., (2007) and Zheng and Wang( 2001) who mentioned that Catechien has been identified as a major components which represents an important contribution especially in the taste of thyme and could be attributed to its antioxidants property as a scavenger of the reactive oxygen species which potent antioxidants inhibiting the photo peroxidation of linolenic acid .

Other phenolic compounds were also detected namely $\mathrm{P}$-coumaric and caffeic acid were 47.51 and $14.12 \mathrm{mg} / \mathrm{g}$, vanillic acid represented 9.22 $\mathrm{mg} / \mathrm{g}$. These obtained results are nearly with the same with those obtained by Moure et al.,(2001), who found same flavonoids and biphenols dimmers were found in thyme extract .

Rosemary (Rosmarinus officinalis) is a widely natural antioxidants in food flavoring. results of HPLC indicated eleven phenolic compounds were separated an eight of them were identified. Salysillic acid was the major phenolic compounds in rosemary $(99.01 \mathrm{mg} / \mathrm{g})$ followed by catechien $(62.50$ $\mathrm{mg} / \mathrm{g}$ ). Moreover , $\mathrm{p}$-coumaric and $\mathrm{p}$-oh benzoic were also detected (42.1 and $13.2 \mathrm{mg} / \mathrm{g}$ ) these obtained results were in accordance with those given by (El-Bastawesy et al. 2008)

Fennel (Foeniculum vulgare) is not widely used as natural antioxidants source of food flavouring but also had antioxidants properties the HPLC 
analysis of fennel extract showed a large number of flavonoids and phenolic acids were identified also. Data in Table (4) showed that Salicylic acid was $9.29 \mathrm{mg} / \mathrm{g}$ and Ferrullic acid $2.75 \mathrm{mg} / \mathrm{g}$ where the most abundant phenolic constitutes in the extract also catechien presented $3.36 \mathrm{mg} / \mathrm{g}$ these data were in accordance with those given by (Yansihtevia et al., 2006 , Weinberg et al., 1999 and Marinova and Yansihtevia, 1996).

Regarding to the same data, it could be noticed that caffeic , chlorogenic, and vanillic have the lowest level of phenolic compounds followed by cinnamic recorded the least concentrate in compare with the major extracted phenolic matters.

Marjoram (Origanum majorana) was natural antioxidants used for spicing and marenading in some areas.Data in the same table presented that Catechien was the predominant phenolic compounds with $27.14 \mathrm{mg} / \mathrm{g}$ followed by Salicylic acid $20.94 \mathrm{mg} / \mathrm{g}$. Also the amount of chlorgenic and benzoic acid seemed to be equal. Only trace amounts of the phenolic acids were detected. Some phenolic compounds were disappeared namely Synergic, P-coumaric and Cinnamic, However there were lower amount of phenolic acids Chlorogenic, Caffeic and Vanillic acids were 4.97, 2.21 and $1.77 \mathrm{mg} / \mathrm{gm}$ respectively. These obtained results were nearly the same with Lien et al., (2008) who stated that catechien and Salicylic acid were presented in marjoram extracts these polyphenols constituent are capable of scavenging more free radicals .

Table (4): Identification of some Phenolic compounds in herbs ethanolic extracts $(\mathrm{mg} / \mathrm{gm})$.

\begin{tabular}{|l|c|c|c|c|}
\hline Phenolic Extract & $\begin{array}{c}\text { Thyme } \\
\text { Extract } \\
\text { (TE) }\end{array}$ & $\begin{array}{c}\text { Rosemary } \\
\text { extract } \\
\text { (RM ) }\end{array}$ & $\begin{array}{c}\text { Marjoram } \\
\text { Extract } \\
\text { (ME) }\end{array}$ & $\begin{array}{c}\text { Fennel } \\
\text { Extract } \\
\text { (FE) }\end{array}$ \\
\hline Catechien & 94.75 & 62.5 & 27.14 & 3.36 \\
Chlorogenic acid & 22.16 & 11.32 & 4.97 & 0.66 \\
Caffien & ----- & 11.02 & --- & 0.45 \\
P-OH Benzoic & 20.80 & 13.2 & 4.65 & 1.34 \\
Ferrulic & 49.19 & 12.33 & --- & 2.75 \\
Caffeic Acid & 14.12 & - & 2.21 & 0.98 \\
Vanillic Acid & 9.22 & - & 1.77 & 0.36 \\
Synergic Acid & 11.18 & - & --- & 0.88 \\
Salicylic Acid & ---- & 99.01 & 20.94 & 9.29 \\
P- coumaric Acid & 47.51 & 42.1 & ---- & --- \\
Cinnamic Acid & 8.13 & 3.21 & ---- & 0.22 \\
\hline
\end{tabular}

\section{B-Oxidative stability of herbs volatile oils and their ethanolic extracts:}

Oxidation rancidity of oils and fats is one of a great concern, since it affects the quality of the food owing the development of various off flavours ,the efficiency of different volatile oils and their ethanolic extracts at the level of $0.2 \mathrm{ml}$ compared with TBHQ (200ppm ) were evaluated and the results are presented in table (5), also, the results for induction time which characterizes the resistance of oil and fats to oxidation and the stabilization factor (S.F), were expressed in Table (5) . 
Results indicated that TBHQ exhibited the highest induction period (11.5) in compare with the others, addition of rosemary or thyme volatile oils at the concentration of $0.2 \mathrm{ml} / \mathrm{l}$ to palm oil resulted in (I.P) 11.2 hours and followed by fennel volatile oil was 10.3 hours at the same concentration .

Results in the same table indicated that The most effective antioxidants is obtained with the palm oil treated with thyme extract at the concentration of $0.2 \mathrm{ml} / /$ represented 10.8 hours. On the other hand, there was a very little difference in induction period in all treated palm oil samples with different extracts at the concentration of $0.2 \mathrm{ml} / \mathrm{l}$ that may be due to the linked more of the volatile compounds to secondary degradation oxidation products. The effectiveness of the inhibitor represents the possibility of blocking the propagation phase through interaction with the peroxyl radical, which is responsible for the duration to reach the IP. For our study we focus on the effectiveness of the inhibitor which expressed as IP sample/ IP of control. (Guzman et al., 2009;Tang et al., 2008 ;and Marinova et al., 2008 )

In general it could be observed, there were appositive correlation between oxidative stability and the type of antioxidants, generally treated palm with thyme and rosemary volatile oil increased the induction period with the concentration of $0.2 \mathrm{ml}$ in compare with their ethanolic extracts at the same concentration and delaying the oxidation process .

Table (5): Oxidative stability of Palm oil treated with different antioxidants.

\begin{tabular}{|c|c|c|c|c|}
\hline Treated oil & $\begin{array}{c}\text { I.P at } \\
100^{\circ} \mathrm{C} \\
\text { (hrs ) }\end{array}$ & $\begin{array}{c}\text { Shelf } \\
\text { Life } \\
\text { (months) }\end{array}$ & $\begin{array}{c}\text { Antioxidant } \\
\text { activity }\end{array}$ & $\begin{array}{l}\text { Increasing } \\
\text { Index \% }\end{array}$ \\
\hline Control & 10.00 & 16.02 & -- & -- \\
\hline Palm oil+TBHQ 200 ppm & 11.50 & 16.93 & 1.15 & 15 \\
\hline Palm oil + RmO $0.2 \mathrm{ml}$ & 11.2 & 17.00 & 1.12 & 12 \\
\hline Palm oil + To $0.2 \mathrm{ml}$ & 11.2 & 16.1 & 1.11 & 11 \\
\hline Palm oil + Fo $0.2 \mathrm{ml}$ & 10.3 & 15.9 & 1.03 & 3 \\
\hline Palm oil + Mo $0.2 \mathrm{ml}$ & 10.3 & 15.9 & 1.03 & 3 \\
\hline Palm oil + RmE $0.2 \mathrm{ml}$ & 10.3 & 15.7 & 1.03 & 3 \\
\hline Palm oil + TE $0.2 \mathrm{ml}$ & 10.8 & 15.9 & 1.08 & 8 \\
\hline Palm oil + FE0.2 ml & 10.5 & 15.9 & 1.05 & 5 \\
\hline Palm oil + MaE $0.2 \mathrm{ml}$ & 10.5 & 15.0 & 1.05 & 5 \\
\hline
\end{tabular}

$\mathrm{RmE}=$ Rosemary extract $. \mathrm{TE}=$ thyme extract $\mathrm{FE}=$ Fennel extract

$\mathrm{Ma} \mathrm{E}=$ Marjoram extract

\section{C- Antimicrobial activity of herbs volatile oils and their ethanolic extracts :}

The antimicrobial activity of some herbs volatile oils and their extracts namely, rosemary, marjoram, thyme and fennel and their ethanolic extracts against some food borne and pathogenic microorganisms by wells diffusion method were assessed and the results presented in Table (6) . Results indicated that, The volatile oils of thyme and rosemary were superior in compare with other volatile oils added, they have an inhibitory effect against Fungi namely, $A$. niger and $A$. flavus, gram negative bacteria Shigella 
flaxnary, salmonella sp. and enterobacter sakazakii , gram positive bacteria Staphylococcus aureus and bacillus cereus. From the microbial analysis it could be reported that rosemary volatile oils have a moderate effect against tested pathogenic strains $\mathrm{G}^{+}$, and fungi. This could be attributed to gram positive bacteria are more sensitive to volatile oil than gram negative bacteria due to that marjoram volatile oil contained borneol, camphor , cineole and limonene which are good antimicrobial compounds., it could be also due to consisted mainly of carvacerol, linalyl acetate and thymol as major components exhibited a complete mycelia inhibition effect on the growth of fungi ( Bourchra et al. 2003 and Juliano et al. 2000)

According to the results of wells diffusion method indicated marjoram volatile oil exhibited a considerable antimicrobial activity against the strains tested particularly gram positive bacteria namely, Staphylococcus aureus and bacillus cereus and gram negative bacteria salmonella sp. These results are in accordance with those given by Kuarta and Koike(1983) and Govaris et al. (2010) who mentioned that antimicrobial effect of marjoram and thyme oils constitutes were found to be phenols, alcohols, aldhydes, ketones, ethers and hydrocarbons can increase that antimicrobial activity and their bacterostatic effect depending on their effectiveness concentration. Data showed that, Thyme volatile had the most antifungal effect. Karaman et al., (2001) reported that thyme oil which rich in carvacerol and thymol possessing high levels of antifungal and antibacterial activity.

Results also, indicated that Fennel and marjoram oil have also displayed high levels of antifungal activity, it has been demonstrated that the antimicrobial effects of volatile oils causing structural and functional damages to the bacterial cell membrane, it also indicated that the optimum range of hydrophobicity is involved the toxicity of volatile oils ( Goni et al. 2009)

Several authors (Viuda-Martos et al., 2008 , Tomaino et al., 2005; and Gergis et al., 1990).) stated that the major component of thyme is thymol, the antibacterial and antifungal activity of these compounds has been confirmed on bacteria.

Thymol has been shown to cause disruption of the cellular membrane, inhibition of ATPase activity, and release of intracellular ATP and other constituents (Oussalah et al., 2006).

Most studies reporting the action of volatile oils against pathogenic bacteria agree that volatile oils are relatively more active against Gram+ve than Gram-ve bacteria (L Viuda-Martos et al., 2008 and Ambert et al., 2001). The cell wall structure of Gram - ve bacteria is constituted essentially with lipopolysaccharides. This constituent avoids the accumulation of oils on the cell membrane (Bezic'et al., 2003).

Results in the same table showed that thyme and marjoram extracts were the most efficient ethanolic extracts against Gram positive bacteria, $S$. aureus (Gram+ve) is more sensitive to thyme than B. cereus (Gram+ve) and E. sakazakii (Gram-ve). Sh. flaxnary and salmonella sp (Gram- ve bacteria) were resistant to the thyme extract while, all ethanolic extracts were effective against fungi activities. this could due to these extracts were rich in some phenolic compounds namely, carnosol, gallic acid chlorogenic acid. . This 
results were in accordance with those given by (Oussalah et al., 2006 and Kim et al. 1995).

(Table 6):- Antimicrobial activity of some herbs volatile oils and their ethanolic extracts (inhibition zone/mm).

\begin{tabular}{|c|c|c|c|c|c|c|c|}
\hline \multirow[b]{2}{*}{ Dils } & \multicolumn{3}{|c|}{$\begin{array}{c}\text { Gram negative } \\
\text { bacteria(g+) }\end{array}$} & \multicolumn{2}{|c|}{$\begin{array}{c}\text { Gram positive } \\
\text { bacteria }\end{array}$} & \multicolumn{2}{|c|}{ Fungi } \\
\hline & 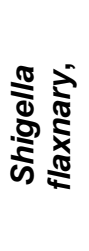 & 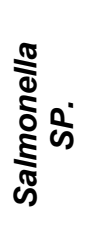 & 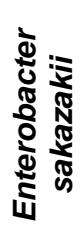 & 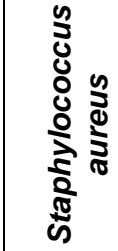 & 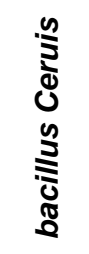 & 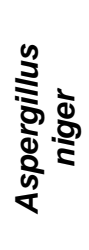 & 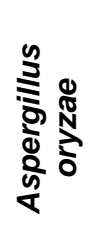 \\
\hline \begin{tabular}{|l|} 
A-Volatile oils \\
Rosemary oil (Ro)
\end{tabular} & 12.1 & 8.2 & 10.7 & 11.1 & 11.3 & 14.0 & 13.1 \\
\hline Thyme oil & + & + & + & + & + & 15.0 & 14.0 \\
\hline Marjoram oil & + & 8.2 & + & 11.0 & 10.7 & 10.0 & 11.0 \\
\hline Fennel oil & 1.9 & 1.7 & NA & 1.1 & 1.1 & 7.0 & 5.0 \\
\hline $\begin{array}{l}\text { B-ethanol extracts : } \\
\text { Rosemary Extract }\left(R_{m} E\right)\end{array}$ & 5.6 & 5.2 & 5.0 & 3.5 & 2.1 & 5.4 & 5.5 \\
\hline Thyme Extract & 8.1 & 8.2 & 7.6 & 7.5 & 7.2 & 8.5 & 8.4 \\
\hline Marjoram extract & 7.2 & 7.1 & 7.5 & 7.3 & 3.0 & 6.1 & 6.1 \\
\hline Fennel extract & 4.1 & NA & NA & NA & NA & 5.1 & 5.1 \\
\hline
\end{tabular}

$+100 \%$ activity $\quad \mathrm{NA}=$ non active

The Minimum Inhibitory Concentration (MIC) of the thyme volatile oil were tested and the results were illustrated in Fig. (1). Results indicated that MIC for thyme oil was varied between $12.5-50 \mu \mathrm{l} / \mathrm{ml}$. The MIC values for $B$. cereus and E. sakazakii were higher than the MIC values of $S$. aureus and fungi. The lowest values were detected for the tested fungi namely Aspergillus niger and Aspergillus oryaze were the same $(12.5 \mu \mathrm{l} / \mathrm{ml})$.

Results in Fig. (1) showed that Staphylococcus aureus have the best susceptibility towards the ethanolic extract of Thymus vulgaris with a MIC value of $15.5_{-} \mu \mathrm{l} / \mathrm{ml}$ followed by Bacillus cereus and salmonella sp. MIC was $31.0 \_\mu \mathrm{l} / \mathrm{ml}$. On the other hand, the methanol extract of thyme demonstrated moderate activities against tested bacteria. The best activity was seen against Staphylococcus aureus and the lowest activity was against Salmonella $s p$.

Finally it could be concluded that volatile oils and their extracts could be a natural source of antioxidants and antimicrobial agents in reducing the total contamination level of foods beside their effect against food pathogen bacteria .

Our obtained results suggested that, thyme and marjoram volatile oil and their extracts have a strong antimicrobial activity. 


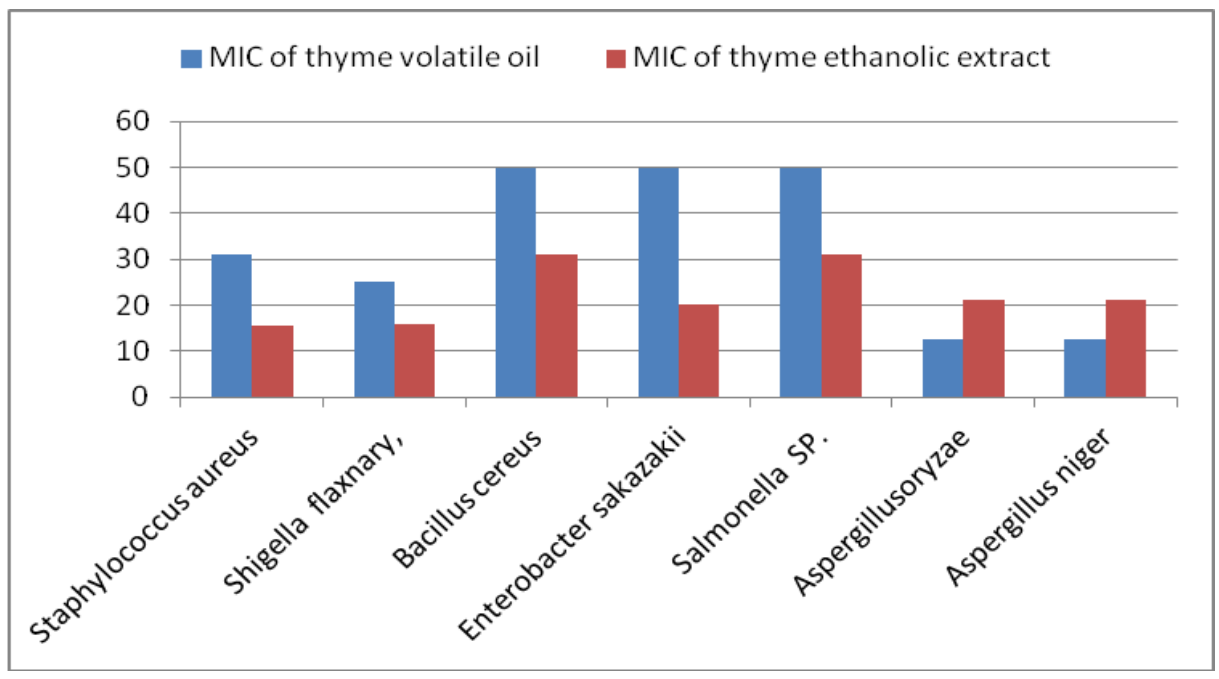

Fig. (1): Minimum Inhibitory Concentration (MIC) of thyme volatile oil and thyme extract $(\mu \mathrm{l} / \mathrm{ml})$.

\section{REFERENCES}

Adms,. R. (2001). Identification of essential oils compounds by gas chromatography guardurpole mass spectrometry carol steam . allured publishing crop.

Andrews, J. M. (2001). Determination of minimum inhibitory concentrations. Journal of Antimicrobial Chemotherapy 48 (Suppl. 1):5-16.

Bakkali, F., Averbeck, S., Averbeck, D., and Idaomar, M. (2008). Biological effects of volatileoils e a review. Food and Chemical Toxicology, 46, 446: 475.

Brand-Williams, B., Cuvelier, M. E., and Berset, C.(1995). Use of a free radical method to evaluate antioxidant activity. LWT-Food Science and Technology, 28, 25-30

Bezic', N., Skocibusic, M., V., and Radonic, A. (2003). Composition and antimicrobial activity of Achillea clavennae L. essential oil. Phototherapy Research, 17, 1037-1040.

Bourchra ,C. Achouri, M. and Hamamouchi,M. (2003).Chemical compostion and anti-fungel activity of essential oils of seven Morocon Labiatae against Botrryis cinerea pers. J. Ethno-pharmacology, 89 : 165-169.

Celiktas ,O., Bedir,E. and Sukan,F. ( 2007). In vitro antioxidant activities of Rosmarinus officinalis extracts treated with supercritical carbon dioxide . food chem., 101(4):1457-1496.

DeMan and DeMan,J.M. (1984). Automated AOM for fat stability .J.A.O.C.S.,(61):534-536.

Demirci, F., Guven, K., Demirci, B., Dadandi, M. and Baser, K. ,(2008). Antibacterial activity of two Phlomis essential oils against food pathogens. Food Control, 19, 1159-1164. 
El-Bastawesy,Amal M. ; Mohamed, Ragaa, H. and EL-Refai,A.A. (2008 ). Chemical and microbial evaluation of rosemary (Rosmarinus officinalis I. ) leaves volatile oil and its methanolic extract. 4 th Arab.Mans.Conf. of Food and Dairy Sci and Tech : 81- 101.

Friedman, M., Henika, P. R., \& Mandrell, R. E. (2002). Bactericidal activities of plant Essential oils and some of their isolated constituents against Campylobacter jejuni, Escherichia coli, Listeria monocytogenese, and Salmonella enterica. Journal of Food Protection, 65, 1545-1560.

Gergis, V., Spiliotis, V.and Poulos, C. (1990). Antimicrobial activity of essential oils from Greek sideritis species, Pharamazie. 45, 70.

Goni, P., Lopez, P., Sanchez, C., Gomez-Lus, R., Becerril, R., and Nerin, C. (2009). Antimicrobial activity in the vapour phase of a combination of cinnamon and clove essential oils. Food Chemistry, 116, 982: 989.

Govaris, A., Solomakos, N., Pexara, A., and Chatzopoulou, P. S. (2010). The antimicrobial effect of oregano essential oil, nisin and their combination against Salmonella Enteritidis in minced sheep meat during refrigerated storage. International Journal of Food Microbiology, 137, 175:180

Guzman D., T. H aiying and S.Salley (2009 ). Synergistic effects of antioxidants on the oxidative stability of soybean oil- and poultry fat based biodiesel. J.A.O.C.S. ,(86): 459: 467.

Hood, J.R., Wilkinson, J.M and Cavanagh, H.M. (2003) Evaluation of common antibacterial screening methods utilized in essential oil research. J. essential Oil Res., Nov/Dec.

Juliano, C., Mattana, A., and Usai, M., (2000). Composition and in vitro antimicrobial activity of the essential oil of Thymus herba-barona Loisel growing wild in Sardinia. Journal of essential Oil Research 12, 516522.

Juliani, H.R. and Simon, J.E.( 2002). Antioxidant of basil. In Janick, J. and Whipkey (eds.). Trends in new crops and new uses. ASHS Press, Alexandra, vab. p 575-579

Karaman, S., Digrak, M., Ravid, V., and Iclim, A. (2001). Antibacterial and antifungal activity of the essential oils of thymus revolutus Celak from Turkey. J. Ethnopharmacol., 76, 183-186.

Kim, J.M., Marshall, M.R., Cornell, J.A., Preston, J.F., Wei, C.I.,(1995). Antibacterial activity of carvacrol, citral and geraniol against Salmonella typhimurium in culture medium and on fish cubes. Journal of Food Science 60, 1364-1368

Kurata ,N. and Koike,S. (1983) . Synergistic antimicrobial effect of ethano,soduim chloride, acetic and esssential oil components. Agric. biol.chem.47:67-75.

Lambert, R. J., Skandamis, P. N., Coote, P., and Nychas, G. J. (2001). A study of minimum inhibitory concentration and mode of action of oregano volatile oil, thymol and carvacrol. Journal of Applied Microbiology, 91, 453-462.

Lien, A.N., Pham-Huy H., and Pham-Huy, C.( 2008). Green tea and health: an overview. J. Food. Agric. Environ. 6(1), 6-13 . 
Marinova and Yansihtevia, (1996). Antioxidative activity of phenolic acids on triglycerols and fatty acids methyl esters from olive oil. Food chemistry (56): 139-145.

Marinova, E. Toneva,A., and Yanishlieva .N. (2008). Synergistic antioxidant effect of $\alpha$ - tocophereol and myricetin on the autooxidation of triglycerides of sunflower oil . Food Chemistry $106: 628-633$.

Mau ,L.J. , Chang, C.N., S.J. and Hung, C.C., (2004). Antioxidant properties of methanolic extracts from Gifola frondosa, Marchella esculenta amd Terminotomyces albuminous mycella. Food Chemistry, 94:415-419.

Mendes, M. J; Sanhueza, and F. Jiong (1997 ) Comparison of rancimat evaluation modes to Assess oxidative stability of fish oil . J.A.O.C.S. (74): 331-332.

Moure, A.; Jose, M.; Demal, F.; Manuel, D. and Carlos, P. (2001). Natural antioxidants from residual source. Food chemistry (72): 145-171.

Nychas, G. J. E., Tassou, C. C., and Skandamis, P. (2003). Antimicrobials from herbs and spices. In S. m. Roller (Ed.), Natural antimicrobials for the minimal processing of foods (pp. 176-200). New York: CRC Press, Woodhead Publishers .

Oussalas, M., Caillet, S. and Lacroix, M. (2006). Michanism of action Spanish oregano, Chinese cinnamon, and Savory essential oils against cell membrane and walls of $\mathrm{E}$. coli $\mathrm{O} 157: \mathrm{H} 7$ and Listeria monocytogenes. Journal of Food Protection, 69, 1046-1055.

Pardun.H. , and Kroll , E. (1972). Fette, Stefen,Anstrichm .74:366 from Deman,L. (1998) automated aom test for fat stability jaocs,61(3): 534536.

Sagdic, O., Karahan, A. G., Ozcan, M., \& Ozkan, G. (2003). Effect of some spice

extracts on bacterial inhibition. Food Science and Technology International, 9, 353:356.

Salgueiro, L., Martins, A. P., and Correia, H. (2010). Raw materials: the importance of quality and safety. A review. Flavour Fragrance Journal, 25, 253.:255

Sendzikiene,E. ,V. Makarevicine and P. Janulis (2005). Oxidation stability of biodiesiel fuel produced from fatty wastes. Polish J. of Environment Studies ,14 (3)335-339.

Skandamis,P.N.and Nychas ,G.E (2001) . Effect of oregano essential oil on micro biological and physico-chemical attributes of minced meat stored in air and modified atmosphere . Journal of applied Microbiology ,91,1011-1022.

SPSS, (2007). Statistical Package for Social Science program version 17 for Windows, SPSS Inc, Chicago, IL , USA

Tang, H. , Wang, A. and Salley, S.O. , (2008) . The effect of natural and synthetic antioxidants on the oxidative stability of biodiesel . J.A.O.C.S 85 (4): 373:382 .

Tomaino, A., Cimino, F., Zimbalatti, V., Venuti, V., Sulfaro, V., De Pasquale, A., and Saija, A. (2005). Influence of heating on antioxidant activity and the chemical composition of some spice essential oils. Food Chemistry, 89(4), 549: 554. 
USFDA, U.S Food and Drug Administration. (2006). Food additive status list. http:// www.cfsan.fda.gov/\%3Ddms/opa-appa.html\#ftn.H Accessed 20.07.09.

Viuda-Martos, M., Ruiz-Navajas, Y., Fernández-López, J., and PerezÁlvarez, J. A. (2008). Antibacterial activity of lemon (Citrus lemon L.) mandarin (Citrus reticulata L.), grapefruit (Citrus paradisi L.) and orange (Citrus sinensis L.) essential oils. Journal of Food Safety, 28, 567: 576.

Wan, J., Wilcock, A. and Conventry, M.J. (1998). The effect of essential oils of basil on the growth of Aeromonas hydrophila and. Pseudomonas Juorescens. J. Appl. Microbiol. 84, 152.

Waskmundzka, M. ; Wianowska, D. ; Szewczyk, K. and Oniszczuk, A. (2007). Effect of sample-preparation methods on the HPLC quantitation of some phenolic acids in plant materials. Acta Chromatographica (19): 227-237

Weinberg, Z. ; Akiri, B. and Kanner, J. (1999). Enhancement of poly phenol recovery from rosmary (Rosmarinus officinalis) and sage (Salvia officinalis) by enzyme assisted ensiling (ENLAC). Journal of Agricultural and Food Chemistry (47): 2959-2962.

Wojdylo A. ; Oszmianski J. and Czemerys R. ( 2007). Antioxidant activity and phenolic compounds in 32 selected herbs . Food Chemistry 105, 490494.

Xiong, H. P., Yang, W. L., Zhang, Y. S., \& Xiao, W. J.(2001). Recent advances in natural plant antioxidants. Natural Product Research and Development, 13(5), 75- 79

Yansihtevia N.; Marinova E. And Pokorony E. (2006) . Natural antioxidants from herbs and spices . Eur .J. Lipid Sci. Tech. $108,776: 793$.

Yen, W. J., Chang, L. W., and Duh, P. D.(2005). Antioxidant activity of peanut seed testa and its antioxidative component, ethyl protocatechuate. Lebensmittel-Wissenschaft und -Technologie, 38, 193-200.

Yoshizaki,Y., H.Yamato, K. Takamine and H. Tamaki .(2010).Analysis of volatile compounds in shochu koji, sake koji and stemed rice by Gas Chromatography-Mass Spectrometry 0 J.Inst.Brew.116 (1),49:55

Zeyada, N.N., Zeitoun, M. and Barbary, O.M. (2007). Extraction , Identification and evaluation of antioxidant activity in some herbs and spices .Alex.J.Fd.Sci, and Technology .

Zheng W. and Wang Y. ( 2001) . Antioxidant activity and phenolic compounds in selected herbs. J.Agric . Food Chem. 49,5165:5170 


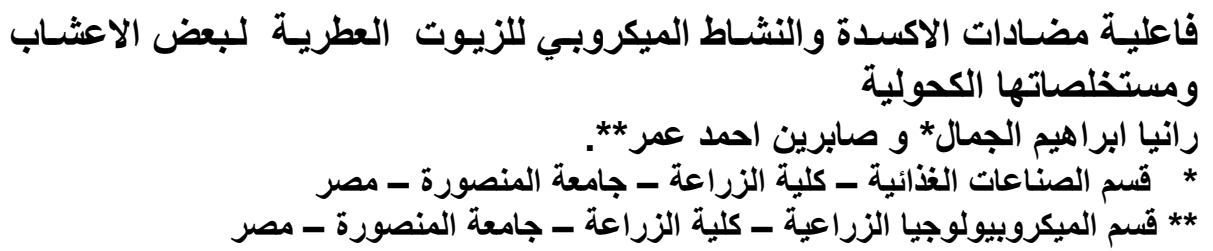

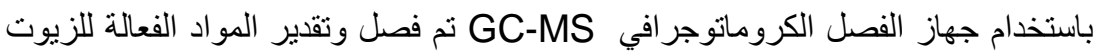

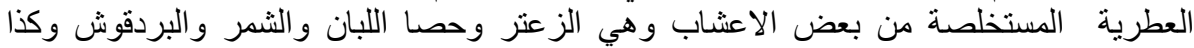

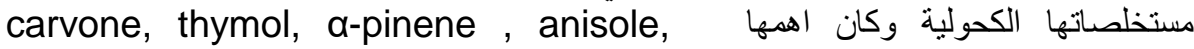
cayrophyllene, , eugenol.

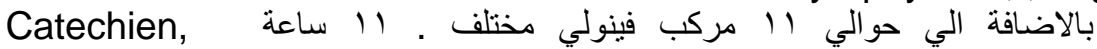
Chlorogenic acid, Caffien, P-OH Benzoic, Ferrulic, Caffeic, Synergic , Salicylic, P- coumaric, Cinnamic and Vanillic acids كما اوضحت النتائج عند تقدير النشاط الميكروبي للزيوت العطرية للاعشاب ومستخلصاتها الكحولية علي خمسة سلالات من الميكروبات وهي aureus, Bacillus cereus, Salmonella sp., Shigella flaxnary and Aspergillus niger and enterobacter sakazakii respectively and جأ Aspergillus oryazae

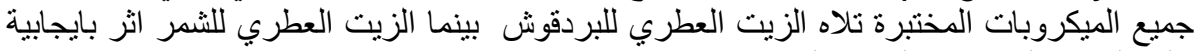

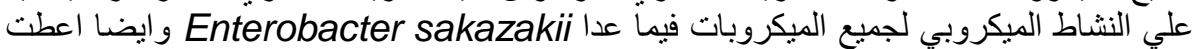

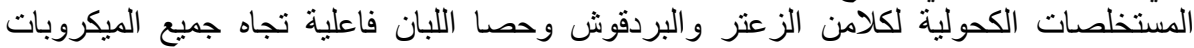

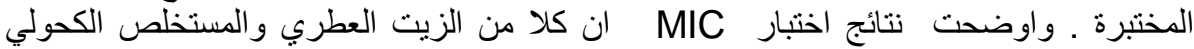

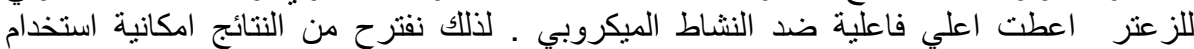

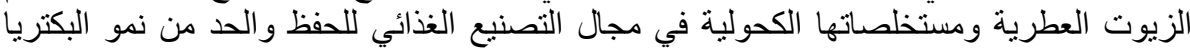

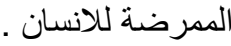

كلية الزراعة - جامعة المنصورة كلية الزراعة - جامعة الاسكندرية

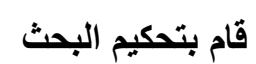

أ. أد / أحمد عبد البحث العزيز الرفاعي أ.د / محمد عبد الحميد زيتون العزئ 